\title{
Evaluasi Pembelajaran Senam di Masa Pandemi Covid 19 Berbasis e-Learning Eldiru
}

\author{
Didik Rilastiyo Budi, S.Pd., M.Pd. \\ Jurusan Penjas Fakultas Ilmu-Ilmu Kesehatan Universitas Jenderal Soedirman \\ Didik.rilastiyo.budi@unsoed.ac.id
}

\begin{abstract}
ABSTRAK
Dampak Covid 19 pada bidang pendidikan membuat proses dan evaluasi pembelajaran di tingkat Perguruan Tinggi tidak dapat terlaksana sebagaimana mestinya. Evaluasi pembelajaran merupakan langkah krusial untuk mengukur prestasi dan tingkat keberhasilan proses belajar mengajar. Adaptasi kondisi pandemi Covid 19 yang membatasi mobilitas menumbuhkan inovasi pembelajaran dan evaluasi menggunakan media daring. Sistem e-Learning ELDIRU yang dikembangkan oleh Universitas Jenderal Soedirman hadir sebagai alternatif penilaian prestasi belajar mahasiswa di mata kuliah pembelajaran senam.
\end{abstract}

Kata Kunci: Evaluasi Pembelajaran, Senam, e-Learning Eldiru, Covid 19

$\mathrm{P}$ endidikan jasmani secara umum didefinisikan sebagai pendidikan melalui aktivitas jasmani dengan tujuan mengembangkan berbagai potensi peserta didik. Pendidikan Jasmani memiliki tujuan yang bersifat menyeluruh (holistik) yaitu mengembangkan domain kognitif, afektif dan psikomotor pada peserta didik (Budi, Hidayat, et al., 2019; Budi \& Listiandi, 2021; Nur et al., 2020). Pembelajaran pendidikan jasmani di tingkat perguruan tinggi dilakukan untuk membekali peserta didik agar memiliki kemampuan dan keterampilan dalam menyampaikan tujuan Pendidikan Jasmani kepada jenjang sekolah serta masyarakat luas .

Karakteristik mata kuliah di prodi pendidikan jasmani sebagian besar merupkan materi keterampilan gerak yang mengharuskan mahasiswa untuk mempraktikan secara langsung berbagai gerakan pada mata kuliah praktik keterampilan dalam proses perkuliahan. Salah satu mata kuliah praktik yang diajarkan kepada mahasiswa yaitu Pembelajaran Senam. Senam adalah suatu aktivitas untuk mengembangkan komponen fisik dan kemampuan gerak yang disusun 
secara sistematis (Sari \& Sugiarto, 2016). Materi perkuliahan senam memiliki kompleksitas gerak tinggi dan mengedepankan aspek kelentukan dan koordinasi yang baik dari berbagai anggota tubuh (Prasetya, 2016; Sari \& Sugiarto, 2016; Widowati \& Rasyono, 2013). Pembelajaran senam bagi mahasiswa dilakukan dalam berapa tahap yaitu senam dasar, senam alat dan pembelajaran senam. Senam dasar terdiri dari rangkaian gerakan senam lantai, seperti roll depan, roll belakang, meroda, dsb. Senam alat terdiri dari gerakan senam di palang sejajar dan balance beam. Sedangkan pembelajaran senam memuat teknik mengajar senam kepada teman sebaya.

Pembelajaran senam di tingkat perguruan tinggi telah mengalami pergeseran metode mengajar dalam kurun waktu empat bulan terakhir. Munculnya wabah virus Covid 19 mengharuskan proses pembelajaran senam dilakukan secara daring (Online) menyusul terbitnya Surat Edaran Menteri Pendidikan dan Kebudayaan No.36962/MPK.A/HK/2020 terkait Pembelajaran Secara Daring dan Bekerja dari Rumah Dalam Rangka Pencegahan Penyebaran Corona Virus Disease 2019 (COVID 19). Merujuk aturan menteri Pendidikan dan Kebudayaan sebagai leading sector bidang pendidikan, sistem pembelajaran daring menjadi langkah alternatif dalam proses maupun evaluasi pembelajaran. Metode pembelajaran dari dengan menerapkan modifikasi materi pembelajaran dapat membantu pengajar dan peserta didik selama pandemi Covid 19. Modifikasi pembelajaran menjadi salah satu solusi yang tepat untuk dapat melaksanakan pembelajaran penjas diberbagai jenjang pendidikan (Agustan et al., 2020; Budi, 2021; Budi, 2015; Listiandi et al., 2020).

Pada program studi yang mengharuskan mahasiswa melakukan praktik langsung dalam proses dan evaluasi pembelajaran, kehadiran pembelajaran secara daring merupakan tantangan tersendiri yang memerlukan strategi khusus. Guna memfasilitasi pembelajaran secara daring pada mata kuliah senam di Prodi Pendidikan Jasmani, Fakultas Ilmu-Ilmu Kesehatan, Universitas Jenderal Soedirman di masa pandemic Covid 19 dilakukan melalui berbagai platform media online seperti E-Learning (Eldiru), Google Meeting, Google Class Room dan Youtube. Secara lebih spesifik, Universitas Jenderal Soedirman mengembangkan sistem Eldiru untuk mendukung keberlangsungan proses pembelajaran bagi mahasiswa Universitas Jenderal Soedirman.

Eldiru juga dikembangkan untuk memfasilitasi dosen dalam melakukan evaluasi hasil belajar mahasiswa, baik berupa tugas terstruktur maupun Ujian Tengah dan Akhir Semester. 
Hasil belajar merupakan produk evaluasi dari penampilan peserta didik selama mengikuti pembelajaran (Budi, Kusuma, et al., 2019; Setiawan et al., 2020). Evaluasi dalam sebuah pembelajaran sangat diperlukan untuk mengukur tingkat pemahaman materi perkuliahan yang telah diberikan oleh dosen.

Langkah evaluasi atau penilaian tugas terstruktur melalui sistem e-Learning Eldiru dilakukan melalui langka sebagai berikut:

1. Mahasiswa membuat video dengan tema pembelajaran tentang teknik mengajar senam.

2. Mahasiswa mengunggah video pembelajaran tersebut melalui platform Youtube.

3. Tautan video kemudian diunggah ke sistem e-Learning Eldiru untuk dapat dinilai oleh tim pengajar.

4. Tampilan hasil unggah video oleh mahasiswa melalui sistem e-Learning Eldiru dapat dilihat pada Gambar 1 di bawah ini.

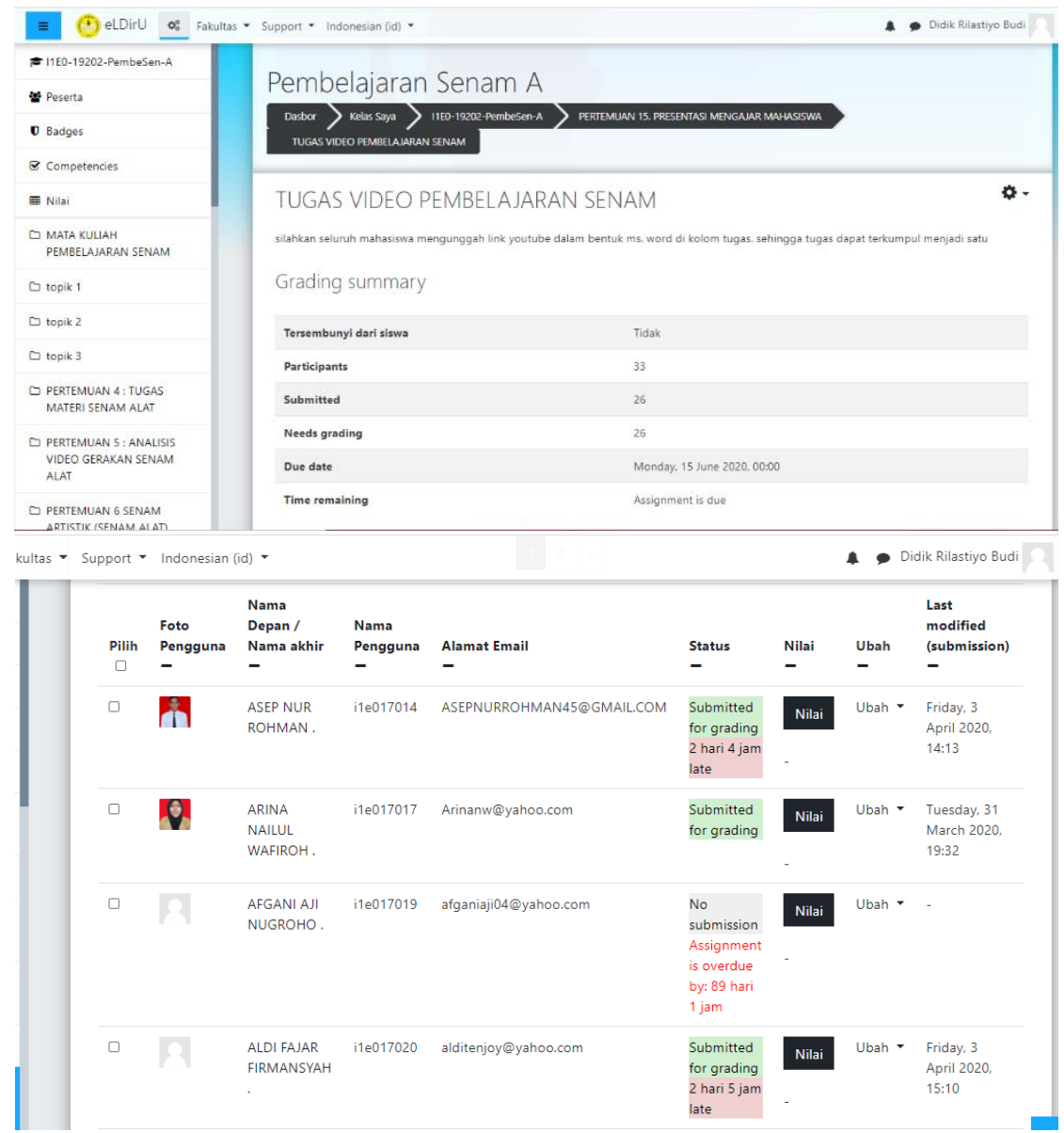

Gambar 1. Tampilan Tugas Videoa Pembelajaran Senam di e-Learning Eldiru 
5. Dosen mengakses video tugas pembelajaran senam melalui tautan youtube yang diunggah oleh mahasiswa dalam akun e-Learning Eldiru pada kolom tugas. Contoh video pembelajaran senam terlihat pada Gambar 2 di bawah ini

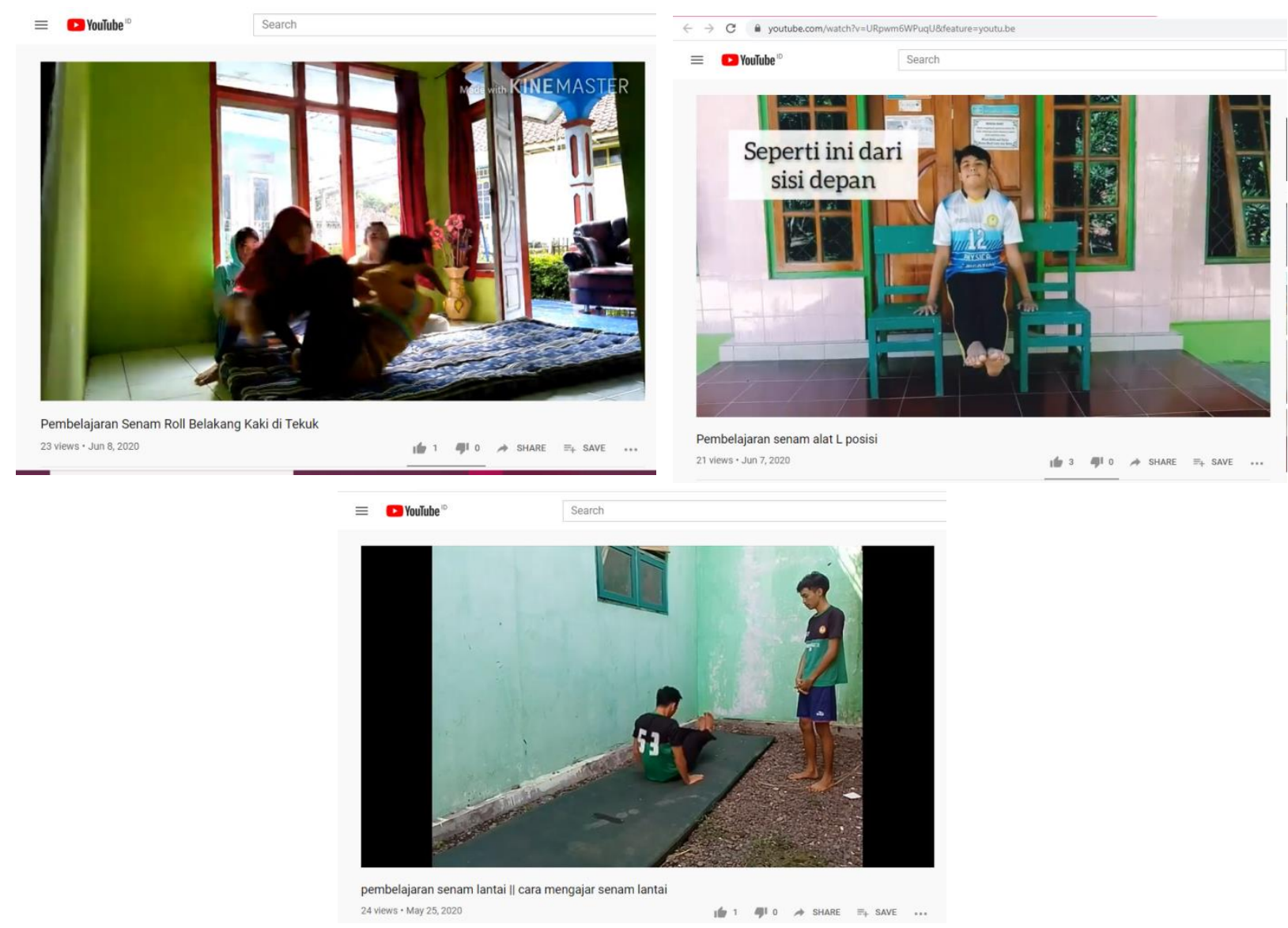

Gambar 2. Video Pembelajaran Senam Oleh Mahasiswa Prodi Penjas Unsoed

Penilaian tugas terstruktur perlu dilakukan oleh seorang pengajar sebagai bagian dari proses evaluasi di mata kuliah pembelajaran senam. Sistem tugas berbasis e-Learning Eldiru akan mempermudah tim pengajar untuk menilai kualitas mengajar mahasiswa, penguasaan kelas, intonasi yang digunakan, tampilan video dan keamanan tempat yang digunakan dalam proses pembelajaran. Evaluasi pembelajaran melalui sistem e-Learning Eldiru tidak hanya terbatas kepada penilaian tugas terstruktur saja yang menitik beratkan kepada keterampilan motorik, akan tetapi evaluasi juga dapat dilakukan untuk mengukur ranah kognitif atau pengetahuan.

Evaluasi pembelajaran pada ranah kognitif melalui sistem e-Learning Eldiru dapat dilakukan pada saat Ujian Tengah Semester (UTS) maupun Ujian Akhir Semester (UAS). Penilaian UTS dan UAS yang dilakukan dengan sistem e-Learning Eldiru membantu pengajar 
memberikan penilaian objektif berdasarkan kemampuan yang dimiliki oleh mahasiswa. Pada penilaian e-Learning Eldiru bentuk soal yang diberikan mengutamakan jenis soal pilihan ganda atau jawaban singkat. Jenis soal semacam ini dinilai lebih mampu menampilkan hasil evaluasi pembelajaran secara objektif dibandingkan dengan jenis soal uraian yang dapat menimbulkan multi intrepetasi antar tim pengajar.

Sistem ujian online melalui e-Learning Eldiru akan merekam jawaban yang telah kerjakan oleh mahasiswa dan hasilnya akan langsung ditampilkan setelah mahasiswa mengakhiri sesi ujian. Melalui sistem tersebut mahasiswa dirangsang untuk mampu berpikir cepat, tepat, dan teliti karena soal ujian memiliki batas waktu yang singkat. Tampilan UTS dan UAS melalui sistem online e-Learning Eldiru dapat dilihat pada Gambar 3 di bawah ini
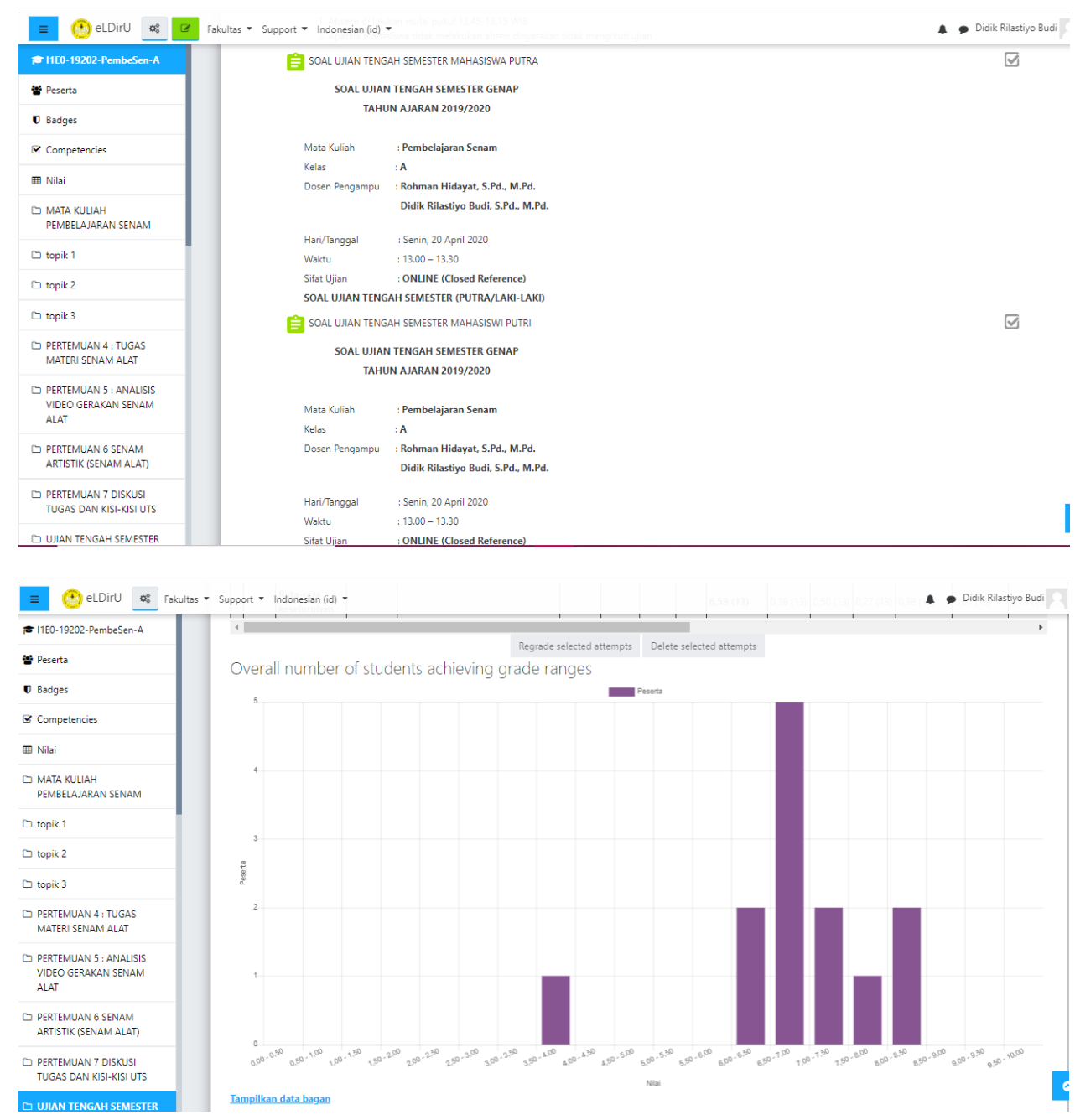


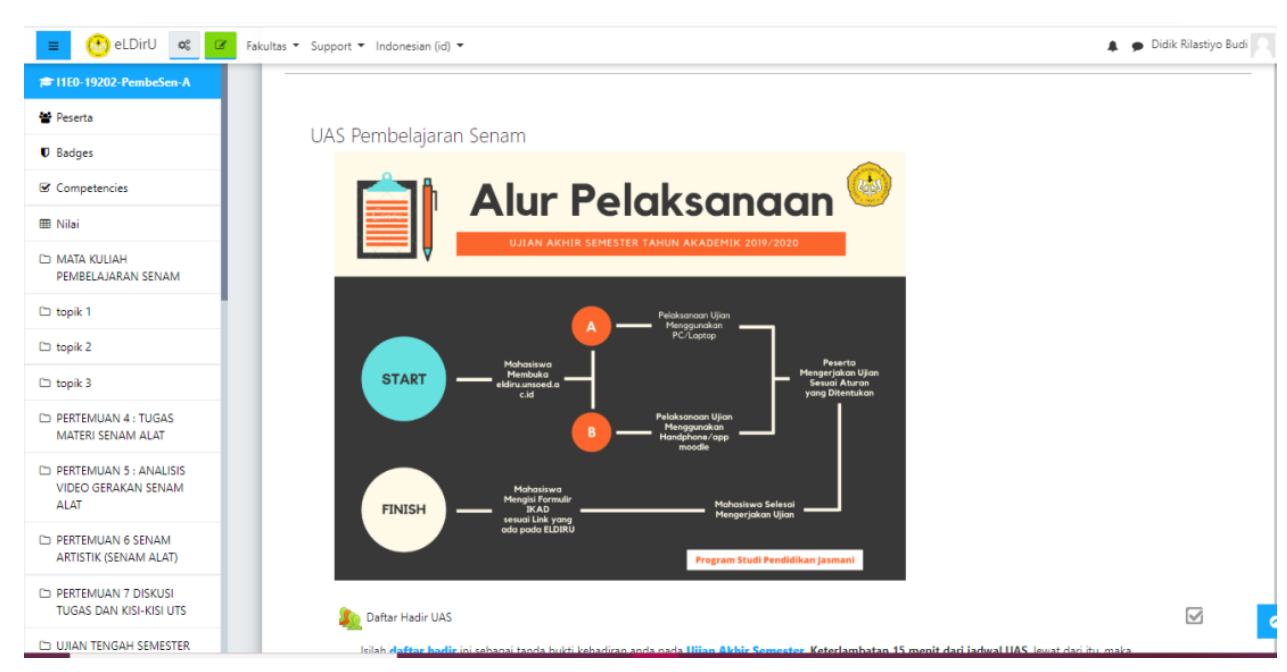

Gambar 3. Tampilan UTS dan UAS Melalui Sistem Online e-Learning Eldiru

Evaluasi pembelajaran online menjadi hal baru dalam mata kuliah pembelajaran senam karena di masa sebelum pandemi Covid 19 penilaian ranah kognitif, afektif dan psikomotor dilakukan secara konvensional. Bentuk evaluasi pada ranah kognitif lebih banyak menekankan pada bentuk soal uraian dibandingkan dengan soal pilihan ganda. Bentuk soal uraian dapat lebih menunjukan kemampuan deskriptif mahasiswa, namun berpotensi memunculkan peniaian subjektif dari tim pengajar yang mungkin berbeda. Melalui sistem e-Learning Eldiru mahasiswa tidak akan dirugikan dengan sistem penilaian berbasis interpretasi pengajar atas jawaba mahasiswa.

Evaluasi pembelajaran online melalui e-Learning Eldiru dalam mata kuliah pembelajaran senam menjadi sebuah alternatif untuk melakukan evaluasi pembelajaran di tengah pandemi Covid 19. Penilaian online memiliki keterbatasan untuk menilai keterampilan gerak dan teknik mengajar senam yang harus dikuasai oleh mahasiswa karena pengajar tidak melihat secara langsung kemapuan mahasiswa. Agar memaksimalkan evaluasi pembelajaran senam perlu dilakukan kombinasi penilaian secara online dan konvensional, sehingga hasil evaluasi lebih objektif. Penilaian online sangat baik untuk mengukur tingkat pemahaman terhadap materi senam, sedangkan penilaian konvensinal sangat tepat untuk mengevaluasi keterampilan gerak senam yang harus dikuasai mahasiswa. 


\section{DAFTAR PUSTAKA}

Agustan, B., Kusmaedi, N., Hendrayana, Y., Abduljabar, B., \& Ginanjar, A. (2020). Modifikasi pembelajaran: hybrid sport education-invasion games competence model terhadap performa permainan bola basket. Jurnal SPORTIF : Jurnal Penelitian Pembelajaran, 6(1), 157-172. https://doi.org/10.29407/js_unpgri.v6i1.14005

Budi, Didik Rilastiyo. (2021). Modifikasi Pembelajaran Pendidikan Jasmani. https://doi.org/https://doi.org/10.31219/osf.io/2ke9y

Budi, Didik Rilastiyo, Hidayat, R., \& Febriani, A. R. (2019). The Application of Tactical Approaches in Learning Handballs. JUARA: Jurnal Olahraga. https://doi.org/10.33222/juara.v4i2.534

Budi, Didik Rilastiyo, Kusuma, M. N. H., Syafei, M., \& Stephani, M. R. (2019). The Analysis of Fundamental Movement Skill in Primary School Student in Mountain Range. 11(Icsshpe 2018), 195-198. https://doi.org/10.2991/icsshpe-18.2019.56

Budi, Didik Rilastiyo, \& Listiandi, A. D. (2021). Model Pembelajaran Dalam Pendidikan Jasmani. https://doi.org/https://doi.org/10.31219/osf.io/xzh3g

Budi, Didik Rilastyo. (2015). Pengaruh Modifikasi Permainan Vobas dan Kebugaran Jasmani Terhadap Peningkatan Kerjasama Siswa dalam Pembelajaran Penjas di SMP. Thesis. http://repository.upi.edu/id/eprint/17605

Listiandi, A. D., Kusuma, M. N. H., Budi, D. R., Hidayat, R., Bakhri, R. S., \& Abdurahman, I. (2020). Pemanfaatan Aplikasi Smartphone untuk Meningkatkan Daya Tahan. Jendela Olahraga, 05(2), 9-17.

Nur, L., Malik, A. A., Juditya, S., Kastrena, E., Widyawan, D., Agustan, B., Budi, D. R., Ardha, M. A. Al, \& Yang, C. B. (2020). Comparison of two types of instruction in physical education. International Journal of Psychosocial Rehabilitation, 24(10), 1785-1793. https://doi.org/10.37200/IJPR/V24I10/PR300205

Prasetya, A. B. (2016). Pengembangan Media Alat Banyu Kayang Pembelajaran Senam Lantai. Journal of Physical Education, Sport, Health and Recreation, 5(3), 114-116.

Setiawan, A., Yudiana, Y., Ugelta, S., Oktriani, S., Budi, D. R., \& Listiandi, A. D. (2020). Hasil Belajar Pendidikan Jasmani dan Olahraga Siswa Sekolah Dasar: Pengaruh Keterampilan Motorik (Tinggi) dan Model Pembelajaran (Kooperatif). TEGAR: Journal of Teaching Physical Education in Elementary School. https://doi.org/10.17509/tegar.v3i2.24513

Wahyu Heny Kartika Sari, Tatok Sugiarto, S. P. (2016). Pengembangan Pembelajaran Senam Lantai Rangkaian Sederhana Siswa Kelas VIII di SMP Negeri 2 ngoro Kabupaten Mojokerto. Jurnal Pendidikan Jasmani.

Widowati, A., \& Rasyono. (2013). Pengembangan Bahan Ajar Senam Lantai Untuk Pembelajaran Senam Dasar Pada Mahasiswa Fakultas Ilmu Keolahragaan Universitas Jambi. Journal of Chemical Information and Modeling . 